Diabetologia (1990) 33:15-23

\title{
Functional and morphological effects of interleukin-1 $\beta$ on the perfused rat pancreas
}

\author{
L. D. Wogensen ${ }^{1}$, V. Kolb-Bachofen ${ }^{3}$, P.Christensen ${ }^{2}$, C. A. Dinarello ${ }^{4}$, T.Mandrup-Poulsen ${ }^{1}$, S.Martin $^{3}$ \\ and J.Nerup ${ }^{1}$ \\ 1 Steno Memorial Hospital, Hagedorn Research Laboratory, Gentofte, \\ ${ }^{2}$ University Institute of Experimental Medicine, University of Copenhagen, The Panum Institute, Copenhagen, Denmark, \\ ${ }^{3}$ Institut für Biophysik und Elektronenmikroskopie, Universität Düsseldorf, FRG, and \\ ${ }^{4}$ Division of Geographic Medicine and Infectious Diseases, Tufts University School of Medicine, Boston, Massachusetts, USA
}

\begin{abstract}
Summary. We recently reported a potentiating effect of recombinant human interleukin- $1 \beta$ on glucose-stimulated insulin release from the isolated perfused pancreas. With the aim of determining whether the stimulatory effect of recombinant interleukin- $1 \beta$ on the $B$ cell in the intact gland was modulated by varying the concentration, time of exposure to recombinant interleukin-1 $\beta$ or B-cell activity, and to elucidate a possible mechanism of action, we measured in the perfused rat pancreas the release of insulin, glucagon and/or prostaglandin $\mathrm{E}_{2}$ according to the following three different protocols: (1) perfusion with $20 \mathrm{ng} / \mathrm{ml}$ of recombinant interleukin- $1 \beta$ for $92 \mathrm{~min}$ at 5 and $20 \mathrm{mmol} / 1 \mathrm{D}$-glucose (2) perfusion with varying concentrations of recombinant interleukin- $1 \beta$ ranging from $0.1 \times 10^{-3} \mathrm{ng} / \mathrm{ml}$ to $100 \mathrm{ng} / \mathrm{ml}$ at 5 and $20 \mathrm{mmol} / 1 \mathrm{D}$-glucose (3) perfusion with $20 \mathrm{ng} / \mathrm{ml}$ of recombinant interleukin- $1 \beta$ at 5,11 or $20 \mathrm{mmol} / / \mathrm{D}$-glucose. Furthermore, in a separate set of experiments we examined the influence of the cytokine on the morphology of the endocrine pancreas. Interleukin- $1 \beta$ stimulated insulin secretion at 11 and $20 \mathrm{mmol} / \mathrm{l} \mathrm{D}$-glucose and potentiated first as well as second phase insulin release in a dose-dependent fashion, with decreasing effect at higher concentrations. Glucagon secretion was also stimulated by recombinant interleukin-1 $\beta$,
\end{abstract}

irrespective of increasing glucose $(5,11,20 \mathrm{mmol} / \mathrm{l})$ and insulin concentrations. The potentiating effect of recombinant interleukin-1 $\beta$ on insulin secretion was evident even after discontinued perfusion with the cytokine, suggesting a priming effect on B-cell function. Furthermore, we did not observe any relation between the recombinant interleukin$1 \beta$ mediated insulin and glucagon release and prostaglandin $\mathrm{E}_{2}$. Electron microscopy of the pancreata perfused with recombinant interleukin- $1 \beta$ revealed significant $B$ cell and to a lesser extent A-cell lysis as well as induction of cell protrusions ("blebs") in B cells only, accompanied by peripheral degranulation and rearrangement of rough endoplasmatic reticulum. We suggest that in addition to a paracrine effect of locally produced interleukin $-1 \beta$ systemic interleukin $-1 \beta$ may have an endocrine effect on A- and B-cell function and viability. Interleukin- $1 \beta$ should be considered to be a physiological modulator of insulin and glucagon secretion e.g. during the acute phase response, but also as a pathogenetic factor in Type 1 (insulin-dependent) diabetes mellitus.

Key words: Interleukin-1, perfused rat pancreas, insulin, glucagon, Type 1 (insulin-dependent) diabetes mellitus.
Interleukin-1 (IL-1) is a family of 17.3-17.5 kilodalton (kD) peptides mainly produced by activated cells of monocytic/phagocytic lineage (macrophages and natural killer cells), but also by parenchymal cells, such as endothelial cells, renal mesangial cells and astrocytes [1]. The acute phase response seems to be induced primarily by IL1 and tumour necrosis factor alpha, (TNF) [1]. Recently, it was demonstrated that IL-1 is distributed throughout the peripheral nervous system innervating several organs [2].

Many of the proposed in vivo effects of $\mathrm{IL}-1$ have been confirmed by in vitro studies. We have reported that recombinant IL-1 (rIL-1), as well as native IL-1, selectively affects pancreatic B-cell activity: stimulation of insulin secretion followed by inhibition and B-cell cytotoxicity [3], dependent on the period of incubation, dose of rIL-1 and degree of metabolic activity of the B cells [4], and we have hypothesized that $\mathrm{IL}-1$ produced in the islets mediates a paracrine destruction of $B$ cells eventually leading to Type 1 (insulin-dependent) diabetes mellitus [5]. The acute phase response is accompanied by increased levels of systemic IL-1 [1] and an endocrine effect on insulin and glucagon secretion from the pancreas may be possible. However, if physiological and pathophysiological actions of circulating IL-1 on the endocrine pancreas are to be studied, islets in organ culture may not be an ideal model for the endocrine pancreas, since the function of the endocrine cells may be affected by the isolation and culture procedures, and since nutrients and other substances do 
not reach the endocrine cells via their physiological route from $B$ to $A$ to $D$ cells [6]. In the islets in the isolated perfused pancreas the endocrine cells can be exposed to substances via the normal vascular supply, and the action of the substance studied without the influence of neuronal or humoral factors.

We have previously reported that recombinant interleukin-1 $\beta(\mathrm{rIL}-1 \beta)$ potentiates glucose-stimulated insulin release [7]. The aim of this study was to test whether rIL$1 \beta$ influences islet cell morphology in the perfused rat pancreas and to achieve further insight into the stimulatory effect of rIL-1 $\beta$ on insulin, glucagon and prostaglandin $E_{2}$ $\left(\mathrm{PGE}_{2}\right)$ release in relation to time, dose, glucose concentration and a possible mechanism of action.

\section{Materials and methods}

\section{Animals}

Male Wistar rats, purchased from Møllegården, (Lille Skensved, Denmark), were housed in our laboratory under controlled conditions of light, temperature and humidity for approximately 10 days before the experiments were performed. The rats were given water and standard chow (Altromin, Chr.Petersen A/S, Ringsted, Denmark) ad libitum. All experiments were initiated between 09.00 and 11.00 hours.

\section{Pancreas perfusion}

Fed rats (body weight $210-220 \mathrm{~g}$ ) randomly allocated to perfusion with either $\mathrm{rIL}-1 \beta$ or $0.9 \% \mathrm{NaCl}$, were anaesthetized by i.p. injections of sodium pentobarbital $(50 \mathrm{mg} / \mathrm{kg})$. The preparation of the isolated pancreas was performed as described by Svenningsen et al. [8]. The in situ pancreas was placed in a $37^{\circ} \mathrm{C}$ prewarmed chamber and was perfused through the celiac trunk and the superior mesenteric artery with a Krebs-Ringer-Bicarbonate buffer (KRB) supplemented with $20 \mathrm{mmol} / \mathrm{L}$ Hepes (KRBH) and $4 \%$ (weight/volume) bovine serum albumin (fraction V, Miles Laboratories Inc., Elkhart, Ind., USA), filtered, heated to $37^{\circ} \mathrm{C}$ before perfusion and kept at $37^{\circ} \mathrm{C}$ in the perfusate reservoirs. The $\mathrm{KRBH}$ was gassed with $95 \%$ $\mathrm{O}_{2} / 5 \% \mathrm{CO}_{2}$ before and during the perfusion to maintain $\mathrm{pH} 7.4$ and to supply the organ with oxygen. The venous effluent was collected on ice after a single passage of the pancreas. Sampling was performed at 3-min intervals, except after a change in glucose concentration, where sampling took place at 1 -min intervals. The perfusion rate was held constant at $3 \mathrm{ml} / \mathrm{min}$. After isolation of the pancreas, the organ was subjected to an equilibration period of $20 \mathrm{~min}$ according to the different experimental protocols. Data from this period were not included in the evaluation of the experiments. Baseline samples were collected from time zero to $12 \mathrm{~min}$. From $12 \mathrm{~min}$ to 72 min (except in protocol I) $0.9 \% \mathrm{NaCl}$ or rIL-1 $\beta$ was added to the perfusate reservoirs in a blinded design according to the protocols (see below). Perfusion experiments not fulfilling the following technical criteria: ischaemia time less than 3 min, perfusion pressure less than $60 \mathrm{~mm} \mathrm{Hg}$, no oedema, continuous gastric secretion or continuous peristalsis of the duodenum, were excluded from the analysis.

\section{Preparation of $r I L-1 \beta$}

Human rIL-1 $\beta$ (R-007) was expressed in Escherichia coli and corresponded to the amino acid sequence $112-269(17 \mathrm{kD})$ of the $\mathrm{pI} 7$ beta form of the natural IL-1 $\beta$ [9]. One unit of rIL-1 $1 \beta$ corresponded to $0.1 \mathrm{ng}$ of protein. The morphology experiments were performed with rIL-1 $\beta$ from two different sources; R-007 and B-44. B-44, supplied by Nordisk Gentofte A/S, (Gentofte, Denmark), was also expressed in E. coli and corresponded to the 153 amino acid, pI 7 beta form of the native IL- $1 \beta$ with the $\mathrm{N}$-terminal amino acid being alanine [10]. The biological activity as estimated in the $\mathrm{C} 3 \mathrm{H} / \mathrm{HeJ}$ mouse thymocyte co-stimulatory assay was $300 \mathrm{WHO} \mathrm{U} / \mathrm{ng}$. Both batches of $\mathrm{rIL}-1 \beta$ were known to be active when tested on isolated islets. From isolated rat islets inhibition of insulin release was obtained with $100 \mathrm{pg} / \mathrm{ml}$ of rIL-1 $\beta$ R-007 and $37 \mathrm{pg} / \mathrm{ml}$ of rIL-1 $1 \beta$ B-44.

\section{Hormone assay}

Rat insulin was determined by a RIA using a guinea pig anti-porcine-insulin serum and ${ }^{125} \mathrm{I}$ porcine ${ }^{14}$ aminoiodoinsulin as tracer (Nordisk Gentofte A/S). Rabbit anti-guinea pig immunoglobulin (Dakopatts, Denmark) was used to precipitate insulin-anti-insulin complexes, separating bound from free tracer. Rat insulin was used as standard (Novo Industry A/S, Bagsvaerd, Denmark). Non-specific binding was $0.3 \pm 0.06 \%, n=13$. The coefficient of variation of independent replicates was $9.3 \pm 0.5 \%, n=39$. All samples were diluted to a concentration between 0.02 and $0.8 \mathrm{nmol} / \mathrm{l}$, in which interval the standard curve showed linearity to serial dilutions. The detection limit was $0.01 \mathrm{nmol} / \mathrm{l}$.

Glucagon was determined utilizing reagents in a commercially available RIA kit (Novo Biolabs, Bagsvaerd, Denmark). Pork glucagon was used as standard. All samples were analysed undiluted. The coefficient of variation of independent replicates was $8.3 \pm 0.9 \%$, $n=9$. Non-specific binding was $4.6 \pm 0.31 \%, n=9$. The detection limit of the RIA was $4.0 \mathrm{pmol} / \mathrm{l}$.

$\mathrm{PGE}_{2}$ was measured by RIA. The RIA previously described [11] and evaluated in control studies by gas chromatography-mass spectrometry [12] included a Sephadex LH-20 chromatographic step which was omitted in the present RIA. Comparison of the original $(\mathrm{x})$ and the modified RIA (y) by regression analysis gave a correlation coefficient $(r)$ of 0.995 . The detection limit of the present RIA was $20 \mathrm{pg} \mathrm{PGE} / \mathrm{ml}$ of sample. The intra- and interassay coefficients of variation was $1.2-3.7 \%$ and $3.6-6.3 \%$, respectively, in the range $0-100 \mathrm{pg} / \mathrm{ml}, n=16$.

\section{Experimental protocols}

I The effect of time (Table 1$)$. Previous studies of rIL- $1 \beta$ in the perfused pancreas employed a perfusion time of $60 \mathrm{~min}$ [7]. With the purpose of investigating the effect of prolonging the exposure time to the cytokine to $92 \mathrm{~min}$, pancreata were perfused with rIL-1 $\beta$ $(20 \mathrm{ng} / \mathrm{ml}, n=5)$ or $0.9 \% \mathrm{NaCl}(n=3)$ in the $20 \mathrm{~min}$ equilibration period and from 0 to $42 \mathrm{~min}$ at $5 \mathrm{mmol} / \mathrm{l} \mathrm{D}$-glucose and from 43 to 72 $\mathrm{min}$ at $20 \mathrm{mmol} / \mathrm{l} \mathrm{D}$-glucose. Each fraction was analysed for insulin.

Table 1. Accumulated insulin release (pmol) from pancreata perfused with recombinant interleukin-1 $(\mathrm{rIL}-1 \beta)(20 \mathrm{ng} / \mathrm{ml})$ or $0.9 \%$ $\mathrm{NaCl}$ for $92 \mathrm{~min}$

\begin{tabular}{lrc}
\hline Group & rIL-1 $\beta$ & $0.9 \% \mathrm{NaCl}$ \\
$n$ & 5 & \multicolumn{1}{c}{3} \\
\hline $0-12$ min & $5.7 \pm 1.4$ & $0.45 \pm 0.05^{\mathrm{a}}$ \\
$13-42$ min & $1.6 \pm 0.4$ & $0.96 \pm 0.05^{\mathrm{a}}$ \\
First phase (43-48 min) & $31 \pm 8.9$ & $1.7 \pm 0.6^{\mathrm{a}}$ \\
Second phase (49-72 min) & $214 \pm 72.5$ & $36 \pm 16.4^{\mathrm{a}}$ \\
\hline${ }^{\mathrm{a}} p<0.05$ & &
\end{tabular}

Accumulated insulin release during specified intervals at $5 \mathrm{mmol} / \mathrm{l}$ D-glucose (0-42 min) and at $20 \mathrm{mmol} / \mathrm{L} \mathrm{D}$-glucose (43-72 min) from pancreata perfused with recombinant interleukin $-1 \beta(20 \mathrm{ng} / \mathrm{mI})$ or $0.9 \% \mathrm{NaCl}$ during the equilibration period and from 0 to $72 \mathrm{~min}$. All values are mean \pm SEM 
Table 2. The effect of varying rIL-1 $\beta$ concentrations on D-glucose induced insulin release

\begin{tabular}{|c|c|c|c|c|c|c|c|c|}
\hline & Control & $\begin{array}{l}\text { rIL-1 } \\
0.1 \times 10^{-3} \\
\mathrm{ng} / \mathrm{ml}\end{array}$ & $\begin{array}{l}\mathrm{rIL}-1 \\
0.1 \mathrm{ng} / \mathrm{ml}\end{array}$ & $\begin{array}{l}\mathrm{rIL}-1 \\
1.0 \mathrm{ng} / \mathrm{ml}\end{array}$ & $\begin{array}{l}\text { rIL-1 } \\
10.0 \mathrm{ng} / \mathrm{ml}\end{array}$ & $\begin{array}{l}\text { rIL-1 } \\
14.0 \mathrm{ng} / \mathrm{ml}\end{array}$ & $\begin{array}{l}\mathrm{rIL}-1 \\
20 \mathrm{ng} / \mathrm{ml}\end{array}$ & $\begin{array}{l}\mathrm{rIL}-1 \\
100 \mathrm{ng} / \mathrm{ml}\end{array}$ \\
\hline $\bar{n}$ & 17 & 8 & 6 & 10 & 7 & 6 & 7 & 5 \\
\hline $\begin{array}{l}0-12 \mathrm{~min} \\
(\mathrm{nmol} / \mathrm{)})\end{array}$ & $0.02 \pm 0.004$ & $0.01 \pm 0.001$ & $0.02 \pm 0.004$ & $0.04 \pm 0.006$ & $0.05 \pm 0.01$ & $0.03 \pm 0.006$ & $0.01 \pm 0.002$ & $0.03 \pm 0.003$ \\
\hline $\begin{array}{l}13-24 \mathrm{~min} \\
(\mathrm{nmol} / \mathrm{l})\end{array}$ & $0.01 \pm 0.001$ & $0.01 \pm 0.001$ & $0.01 \pm 0.001$ & $0.02 \pm 0.004$ & $0.02 \pm 0.002$ & $0.03 \pm 0.006$ & $0.01 \pm 0.0$ & $0.02 \pm 0.003$ \\
\hline $\begin{array}{l}\text { 2nd Phase } \\
31-72 \mathrm{~min} \\
\text { (pmol) }\end{array}$ & \pm 28 & \pm 19 & \pm 23 & \pm 33 & \pm 86 & \pm 74 & \pm 52 & \pm 71 \\
\hline
\end{tabular}

Release of insulin during specified intervals at $5 \mathrm{mmol} / \mathrm{L} \mathrm{D}$-glucose $(0-24 \mathrm{~min})$ and at $20 \mathrm{mmol} / \mathrm{l} \mathrm{D}$-glucose $(25$ to $72 \mathrm{~min})$ from pancreata perfused with either $0.9 \% \mathrm{NaCl}$ (control) or varied concentrations of recombinant interleukin-1 $\beta$ (rIL-1 $\beta$ ) from 12 to 72 min. First (1st) and second ( $2 \mathrm{nd}$ ) phase insulin release in response to $20 \mathrm{mmol} / \mathrm{D}$-glucose is given as accumulated insulin. All values are mean $\pm \mathrm{SEM}$

II The effect of $r$ IL-1 $\beta$ concentration (Table 2). Eight groups of pancreata were perfused in the equilibration period and from 0 to 24 min with $\mathrm{KRBH}$ containing $5 \mathrm{mmol} / 1 \mathrm{D}$-glucose and from 25 to $72 \mathrm{~min}$ with KRBH containing $20 \mathrm{mmol} / \mathrm{l}$ of D-glucose. rIL-1 $\beta$ $\left(0.1 \times 10^{-3}(n=8), 0.1(n=6), 1.0(n=10), 10(n=7), 14(n=6), 20\right.$ $(n=7)$ or $100 \mathrm{ng} / \mathrm{ml}(n=5))$ or $0.9 \% \mathrm{NaCl}(n=17)$ was added to the perfusate from 13 to $72 \mathrm{~min}$. Each fraction of effluate was analysed for insulin.

III The effect of glucose concentration (Fig.1, 2 and 3). Three groups of pancreata were perfused with $\mathrm{KRBH}$ containing 5 $(n=13), 11(n=20)$ or $20 \mathrm{mmol} / \mathrm{l}$ of D-glucose $(n=15)$ during the period of equilibration and from 0 to $72 \mathrm{~min}$. In the period from 73 to $84 \mathrm{~min}$ the glucose concentration was changed as follows in the three groups: from $5 \mathrm{mmol} / \mathrm{l}$ to $11 \mathrm{mmol} / \mathrm{l}$ glucose and from 11 or $20 \mathrm{mmol} / 1 \mathrm{D}$-glucose to $5 \mathrm{mmol} / \mathrm{l} \mathrm{D}$-glucose, respectively. The pancreata were perfused with $20 \mathrm{ng} / \mathrm{ml}$ of rIL- $1 \beta$ or $0.9 \% \mathrm{NaCl}$ from 13 to $72 \mathrm{~min}$. Insulin was assayed in each collected fraction. Glucagon levels were analysed in every second fraction from 0 to $72 \mathrm{~min}$ and from 72 to $81 \mathrm{~min}$ in each collected fraction. $\mathrm{PGE}_{2}$ release was analysed in samples collected at $6,21,36,66$, and $84 \mathrm{~min}$.

$I V$ Islet morphology at ultrastructural level (Table 3 and Fig. 4 a, $b$, and $c)$. Nine pancreata were perfused during the equilibration period and from 0 to $42 \mathrm{~min}$ with $\mathrm{KRBH}$ containing $5 \mathrm{mmol} / \mathrm{l}$ of Dglucose and from 43 to $72 \mathrm{~min}$ with $\mathrm{KRBH}$ containing $20 \mathrm{mmol} / \mathrm{L} \mathrm{D}$ glucose. From 12 to 72 min $0.9 \% \mathrm{NaCl}(n=4)$ or rIL-1 $3(20 \mathrm{ng} / \mathrm{ml}$ of $\mathrm{R}-007, n=3$ or $15 \mathrm{ng} / \mathrm{ml}$ of $\mathrm{B}-44, n=2$ ) was added to the perfusate reservoirs in a blinded design. At the end of the experimental period the pancreata were perfused with $25 \mathrm{ml} 1 \%$ glutaraldehyde in natriumcacodylate buffer, $\mathrm{pH}$ 7.2. The fixed pancreata were removed, the spleen-near part dissected and cut into $3 \mathrm{~mm} \times 3 \mathrm{~mm}$ pieces while bathed in the buffered glutaraldehyde. After further fixation for $1 \mathrm{~h}$ at $4^{\circ} \mathrm{C}$ in $1 \%$ glutaraldehyde, tissue pieces were washed and postfixed with cacodylate buffered $\mathrm{OsO}_{4}(1.5 \%)$ for $2 \mathrm{~h}$. Specimens were washed 3 times in cacodylate buffer and were stored in this buffer for a maximum of 10 days. After dehydration with graded ethanol dilutions the tissue was embedded in epoxy resin according to Spurr [13]. All specimens were sectioned semi-thin and screened for islets after staining with toluidine blue, islet containing tissue was sectioned ultra-thin. For quantitation of lysis events, on micrographs at a final magnification of $5000 \times$, the number of A and B cells was counted. Lysis was regarded as positive when cytoplasm did not exhibit the usual intermediate contrast but stained opaque. Lysis was additionally confirmed by screening the respective islet cells at higher magnifications for disrupted plasma membrane.

\section{Statistical analysis}

Results are expressed as means \pm SEM. In protocol III the hormone release from 12 to $72 \mathrm{~min}$ was calculated as the increase in hormone release above mean pre-infusion level (average of baseline level in the particular experiment). The two-tailed Mann-Whitney rank sum test was used to test differences between two groups of rats. The Kruskall-Wallis test of variance was used when comparing more than two groups of unpaired data (protocol II). The Friedman test of variance was used when comparing more than two groups of paired data (protocol III). Chi-squared test was used in the morphology study. The level of significance chosen was $5 \%$.

\section{Results}

\section{The effect of 92 min of exposure to $1 L-1 \beta$ on D-glucose-induced insulin release}

rIL-1 $\beta$ caused a transient increase in insulin release from 0 to $42 \mathrm{~min}$, not observed in control pancreata (data not shown), causing a higher total release of insulin from 0 to

Table 3. Islet and cell count from pancreata perfused with recombinant interleukin- $1 \beta$ or $0.9 \% \mathrm{NaCl}$

\begin{tabular}{|c|c|c|c|c|c|c|c|c|c|}
\hline \multirow[t]{2}{*}{ Group } & \multirow{2}{*}{$\begin{array}{l}\text { No. of } \\
\text { experiments }\end{array}$} & \multirow{2}{*}{$\begin{array}{l}\text { No. of } \\
\text { islets }\end{array}$} & \multirow{2}{*}{$\begin{array}{l}\text { Total no. of } \\
\text { cells counted }\end{array}$} & \multicolumn{3}{|c|}{ No. of intact cells } & \multicolumn{3}{|c|}{ No. of lysed cells (\%) } \\
\hline & & & & $\overline{\mathrm{A}}$ & $\mathrm{B}$ & $\overline{\text { other }}$ & $\bar{A}$ & B & other \\
\hline$\overline{\mathrm{NaCl}}$ & 4 & 34 & 1553 & 315 & 1012 & 139 & $\begin{array}{l}22(6.5 \%) \\
p=0.04\end{array}$ & $\begin{array}{l}64(6.0 \%) \\
p<0.001\end{array}$ & $\begin{array}{l}1(0.7 \%) \\
\text { NS }\end{array}$ \\
\hline rIL-1 $\beta$ & 5 & 31 & 1882 & 398 & 1043 & 119 & $49(11.0 \%)$ & $271(20.6 \%)$ & $2(1.7 \%)$ \\
\hline
\end{tabular}

Nine pancreata were perfused with recombinant interleukin- $1 \beta(15-20 \mathrm{ng} / \mathrm{ml}, n=5)$ or $0.9 \% \mathrm{NaCl}$ from 12 to $72 \mathrm{~min}$ at $5(0-42 \mathrm{~min})$ or $20 \mathrm{mmol} / /$ of $\mathrm{D}$-glucose ( 43 to $72 \mathrm{~min}$ ). After termination of the experimental period the pancreata were fixed by perfusion with $1 \%$ glutaraldehyde and postfixed in $1.5 \% \mathrm{OsO}_{4}$. Islets, intact and lysed cells were counted in ultrathin slices. A Chi-square test was used 
$12 \mathrm{~min}$ and from 13 to $42 \mathrm{~min}$ in the rIL-1 $\beta$ perfused pancreata (Table 1 ). Both groups exhibited a biphasic insulin release in response to $20 \mathrm{mmol} / \mathrm{l}$ of D-glucose. However, insulin release during first and second phase was significantly higher $(p<0.05)$ in the rIL-1 $\beta$ perfused group of pancreata compared to the control group.

\section{Dose-response relationship between $r I L-1 \beta$} concentrations and $D$-glucose-induced insulin release

All groups showed identical and stable insulin baseline levels from 0 to $24 \mathrm{~min}$ and exhibited first as well as second phase insulin release in response to $20 \mathrm{mmol} / 1$ of D-glucose (Table 2). The potentiating effect of rIL-1 $\beta$ on glucose-stimulated insulin release was dependent on the concentration of the cytokine in the perfusate buffer (first phase: $p<0.005$, second phase: $p<0.005$, Kruskall Wallis test of variance). However, at concentrations exceeding $14 \mathrm{ng} / \mathrm{ml}$ the second phase insulin release declined, indicating a bimodal effect of rIL-1 $\beta$ on glucose-stimulated insulin release. At the two lowest concentrations of rIL-1 $\beta$, first as well as second phase insulin release was decreased. However, this decrease was not statistically significant.

\section{The influence of glucose concentration on the potentiating effect of $r I L-1 \beta$ on stimulated insulin release}

The baseline concentration of insulin in rIL-1 $\beta$ perfused pancreata and in the control group was identical at 5,11 and $20 \mathrm{mmol} / \mathrm{l}$ of D-glucose. At $5 \mathrm{mmol} / \mathrm{l}$ of D-glucose $(0$ to $72 \mathrm{~min}$ ) no significant difference in insulin release was observed comparing rIL-1 $\beta(n=6)$ and $0.9 \% \mathrm{NaCl}(n=7)$ perfused pancreata. Stimulation with $11 \mathrm{mmol} / \mathrm{l} \mathrm{D}$-glucose induced the characteristic first and second phase insulin release in both groups. The amount of insulin released during the first phase (73 to $78 \mathrm{~min}$ ) was $6.5 \pm 1.1$ pmol in the rIL-1 $\beta$-treated group and $2.2 \pm 0.7 \mathrm{pmol}$ in the control group $(p<0.05)$ and during the second phase (79 to $84 \mathrm{~min}$ ) $9.0 \pm 2.2 \mathrm{pmol}$ and $2.5 \pm 0.7 \mathrm{pmol}$, respectively $(p<0.05)$ (Fig. $1 \mathrm{a})$. At 11 and $20 \mathrm{mmol} / \mathrm{l}$ of D-glucose a steady increase in insulin secretion was observed from 12 to $72 \mathrm{~min}$ in the control groups $(p<0.005, n=8$, $p<0.0005, n=8$ ). However, rIL-1 $\beta$ induced a more pronounced release of insulin at both glucose concentrations ( $p<0.0005, n=12, p<0.0005, n=7$, respectively) (Fig. 2 a and $3 \mathrm{a}$ ). At $11 \mathrm{mmol} / \mathrm{l}$ of D-glucose rIL-1 $\beta$ induced a significantly higher insulin level in the period from 42 to $72 \min (p<0.01$ at each time point) and the insulin released above the baseline level was $42 \pm 10$ pmol compared to $0.4 \pm 4.8 \mathrm{pmol}$ in the control group $(p<0.01)$. However, the total amount of insulin released from 13 to $72 \mathrm{~min}$ in the two groups did not differ significantly (rIL$1 \beta: 75.4 \pm 11.2$ pmol, control: $49.8 \pm 12.7$ pmol, $p=0.10$ ) (Fig. 2 a). At $20 \mathrm{mmol} / \mathrm{l}$ of D-glucose the insulin level was significantly higher in the rIL-1 $\beta$ group only at $66 \mathrm{~min}$ $(p<0.05)$. The amount of insulin released above baseline level in the IL-1 $\beta$ group was $162 \pm 45$ pmol compared to $83 \pm 15$ pmol in the control group $(p=0.06)$. The total amount of insulin released in the two groups did not differ,

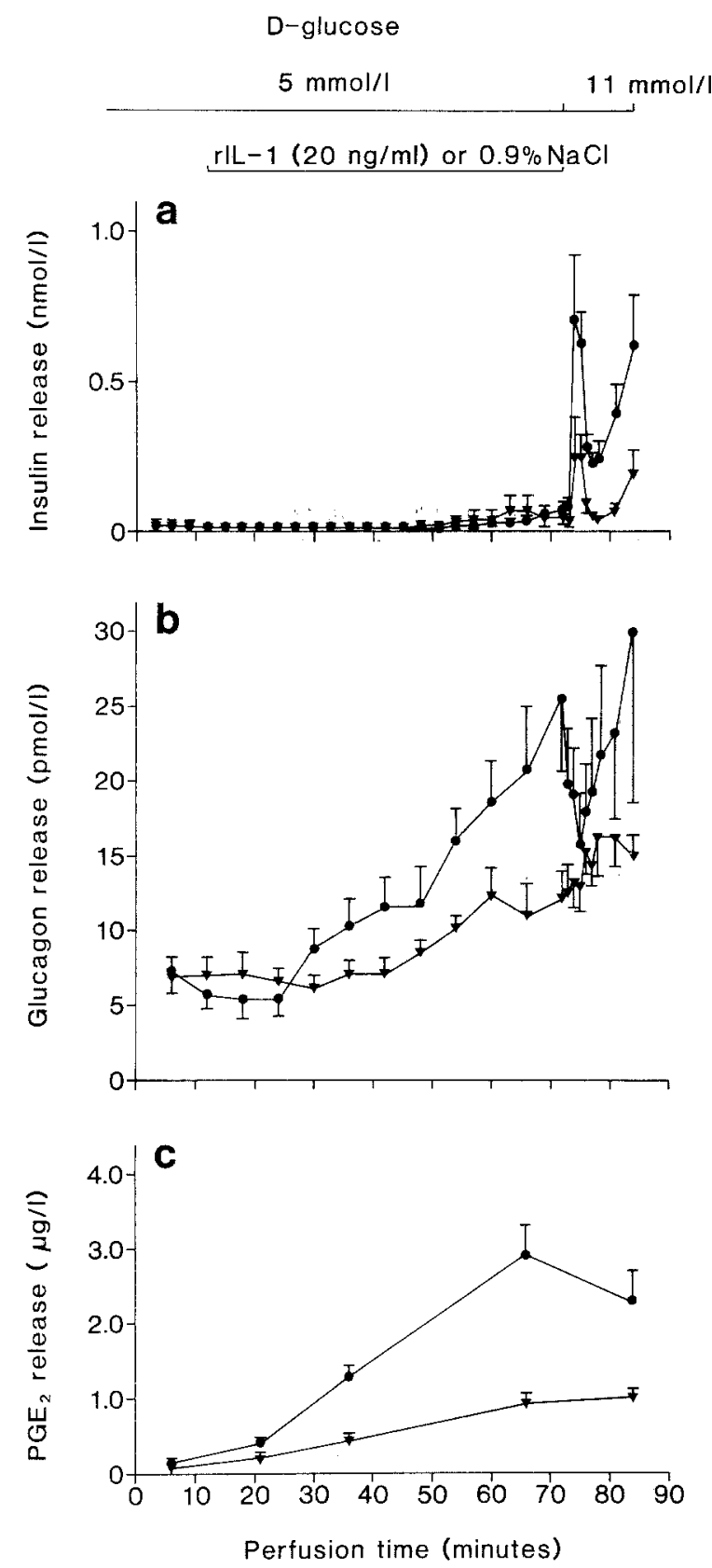

Fig. 1 a-c. Release of insulin (a), glucagon (b) and prostaglandin $\mathrm{E}_{2}$ (c) at $5 \mathrm{mmol} / \mathrm{l} \mathrm{D}$-glucose -0 to $72 \mathrm{~min}$ - and in response to 11 $\mathrm{mmol} / \mathrm{l} \mathrm{D}$-glucose -72 to $84 \mathrm{~min}$ - from rat pancreata perfused with $20 \mathrm{ng} / \mathrm{ml}$ of recombinant interleukin $-1 \beta(n=6)(\bullet)$ or $0.9 \% \mathrm{NaCl}$ $(n=7)$ (A) from 12 to $72 \mathrm{~min}$ (Protocol III)

rIL-1ß: $372 \pm 78$ pmol, control: $238 \pm 38$ pmol $(p=0.15)$ (Fig. 3 a). Lowering the D-glucose concentration from 11 or $20 \mathrm{mmol} / \mathrm{l}$ caused a rapid, physiological decrease in insulin release in all groups.

At 5 and $11 \mathrm{mmol} / 1$ of D-glucose rIL-1 $\beta$ and $0.9 \%$ $\mathrm{NaCl}$ perfused pancreata exhibited stable and identical baseline levels of glucagon from 0 to $12 \mathrm{~min}(p>0.05)$. At $20 \mathrm{mmol} / \mathrm{l}$ of $\mathrm{D}$-glucose the glucagon baseline level in the control group was higher than in the rIL-1 $\beta$ group $(p<0.005)$. This could be explained by an increased glucagon release secondary to a lower insulin level (Fig. 3 b) [6]. However, the difference in insulin secretion between 


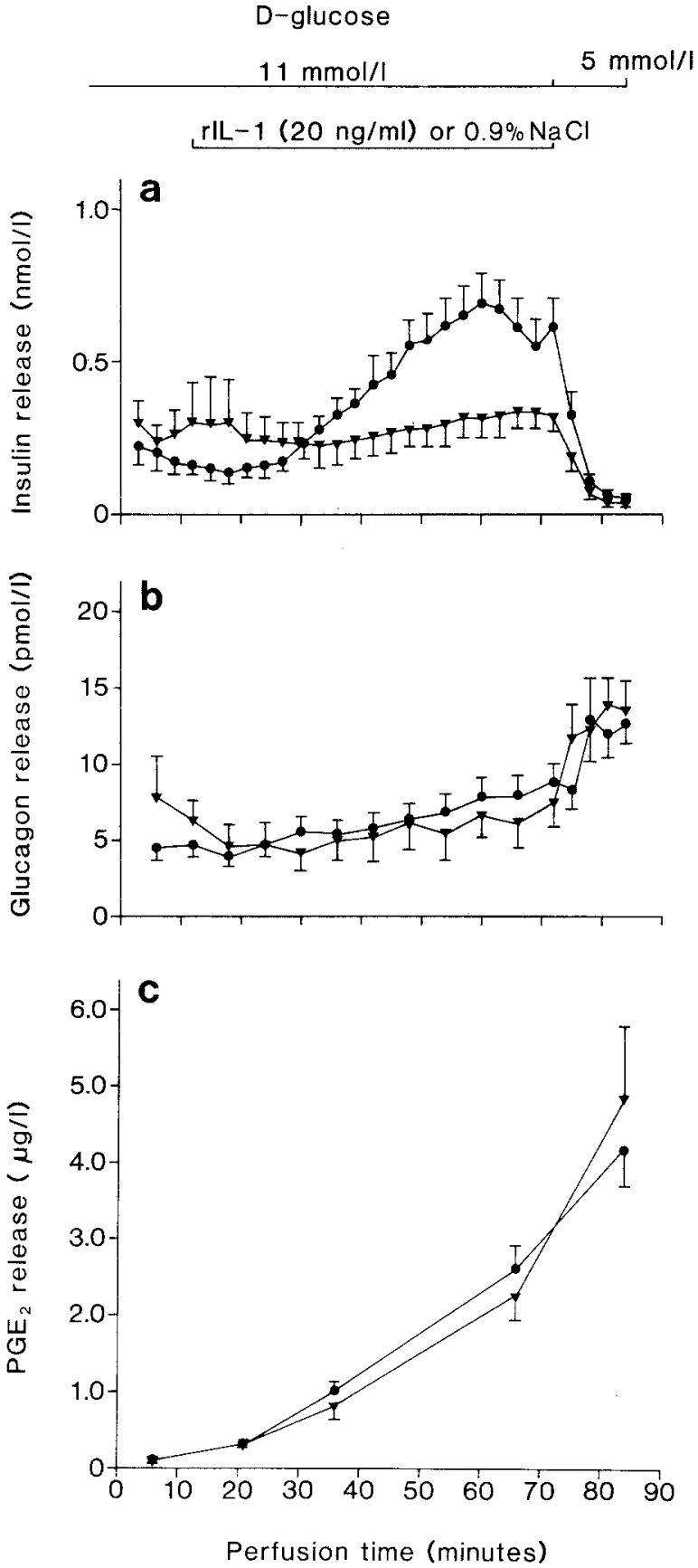

Fig. 2 a-c. Release of insulin (a), glucagon (b) and prostaglandin $E_{2}$ (c) at $11 \mathrm{mmol} / \mathrm{l} \mathrm{D}$-glucose -0 to $72 \mathrm{~min}$ - and at $5 \mathrm{mmol} / 1 \mathrm{D}$-glucose -72 to $84 \mathrm{~min}$ - from rat pancreata perfused with $20 \mathrm{ng} / \mathrm{ml}$ of recombinant interleukin-1 $\beta(n=12)(\bullet)$ or $0.9 \% \mathrm{NaCl}(n=8)(\boldsymbol{\Delta})$ from 12 to $72 \mathrm{~min}$ (Protocol III)

the two groups was not significant $(p=0.61)$. At $5 \mathrm{mmol} / \mathrm{l}$ of D-glucose a statistically significant increase in glucagon secretion was observed from 13 to $72 \mathrm{~min}$ in both groups (rIL-1 $\beta$ : $p<0.005$, control: $p<0.0005$ ). Co-perfusion with $\mathrm{rIL}-1 \beta$ induced a more pronounced release of glucagon, which was significant at 54, 60,66 and $72 \mathrm{~min}$ $(p<0.01)$. The shift from 5 to $11 \mathrm{mmol} / \mathrm{l} \mathrm{D}$-glucose induced an instant decrease $(p<0.05)$ followed by a rapid increase $(p<0.05)$ in glucagon release in the rIL-1 $\beta$ group, whereas the glucagon secretion in the control

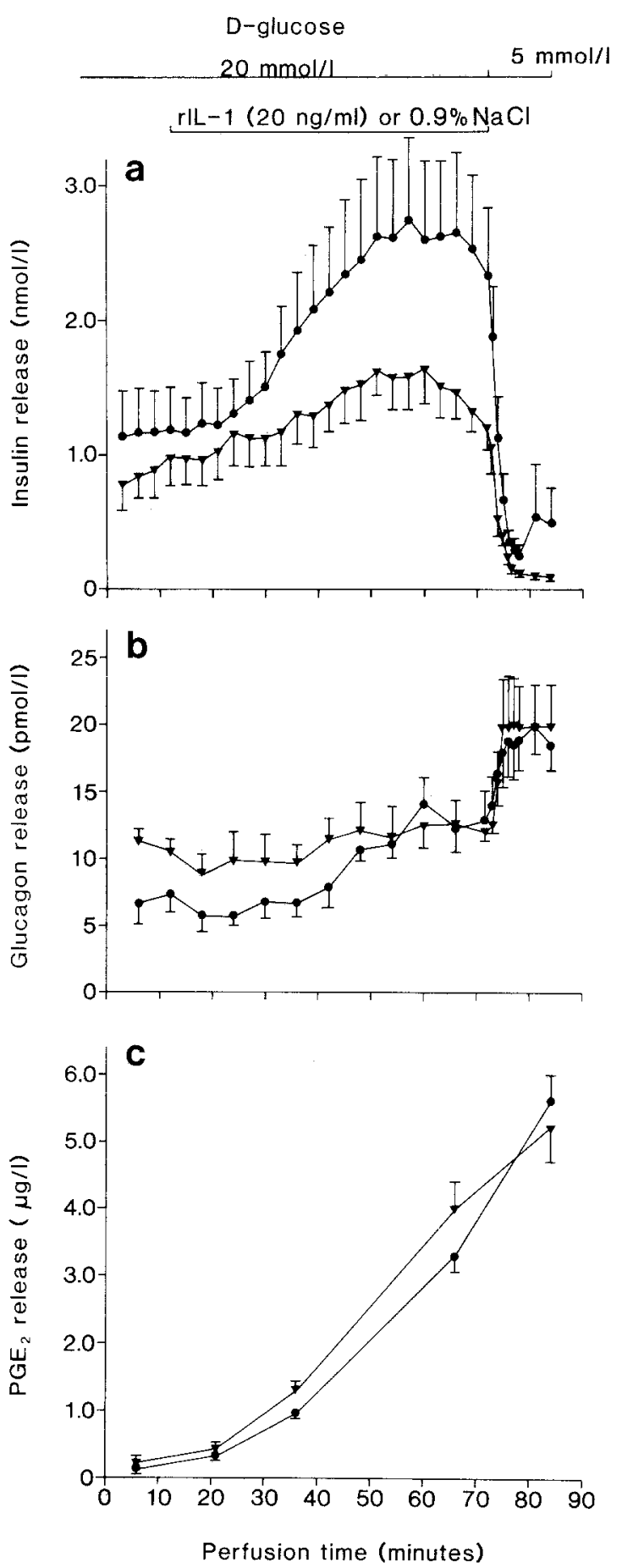

Fig. 3 a-c. Release of insulin (a), glucagon (b) and prostaglandin $E_{2}$ (c) at $20 \mathrm{mmol} / \mathrm{l} \mathrm{D}$-glucose - 0 to $72 \mathrm{~min}$ - and $5 \mathrm{mmol} / 1 \mathrm{D}$-glucose 72 to $84 \mathrm{~min}$ - from rat pancreata perfused with $20 \mathrm{ng} / \mathrm{ml}$ of recombinant interleukin-1 $\beta(n=7)(\bullet)$ or $0.9 \% \mathrm{NaCl}(n=8)(\Delta)$ from 12 to $72 \min$ (Protocol III)

group was unaffected by the change in glucose concentration (Fig. 1 b). At 11 and $20 \mathrm{mmol} / 1 \mathrm{D}$-glucose a significant increase in glucagon release was observed exclusively in the rIL-1 $\beta$ perfused pancreata $(p<0.0005)$, although no difference in glucagon level was observed between the control and the rIL-1 $\beta$ perfused pancreata at each glucose level $(p>0.05)$ (Fig.2 b and $3 \mathrm{~b}$ ). All groups responded with an accentuated glucagon release in re- 

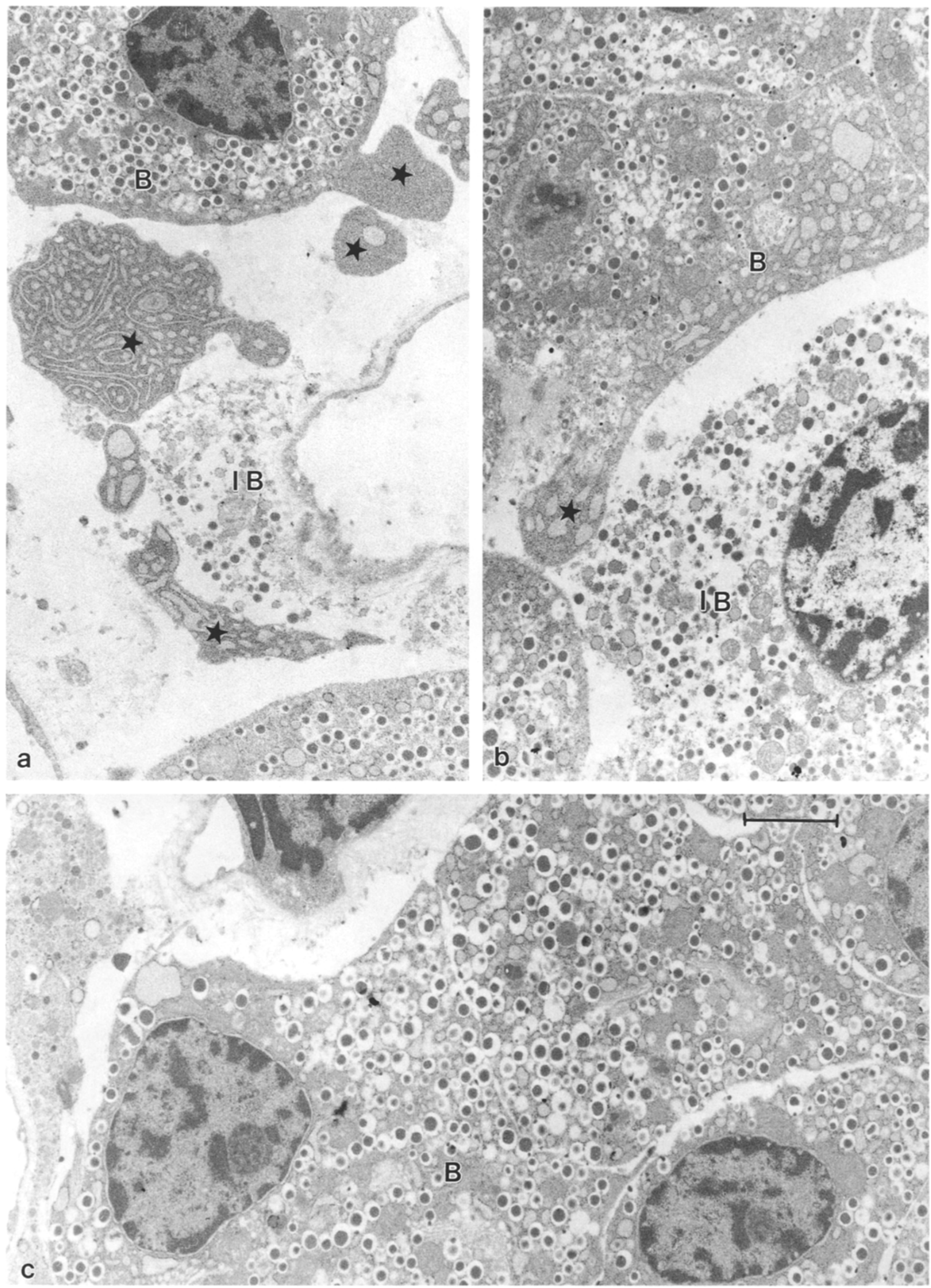
sponse to $5 \mathrm{mmol} / \mathrm{L} \mathrm{D}$-glucose in the interval from 73 to $84 \mathrm{~min}$.

During perfusion with $5 \mathrm{mmol} / \mathrm{l}$ of $\mathrm{D}$-glucose the baseline level of $\mathrm{PGE}_{2}$ at $6 \mathrm{~min}$ was $0.06 \pm 0.027 \mu \mathrm{g} / \mathrm{l}$ in control experiments compared to $0.14 \pm 0.015 \mu \mathrm{g} / \mathrm{l}$ in rIL- $1 \beta$ perfused pancreata $(p<0.05)$. A marked increase in $\mathrm{PGE}_{2}$ release was observed in both groups, (rIL-1 1 : $p<0.0005$, control: $p<0.0005$ ). The rIL-1 $\beta$ co-perfused pancreata exhibited at each time point a statistically significant higher level of $\mathrm{PGE}_{2}$ in the effluate compared to the control group $(0.001<p<0.02)$ (Fig. 1 c). At 11 and $20 \mathrm{mmol} / \mathrm{l}$ of $\mathrm{D}$-glucose the baseline level of $\mathrm{PGE}_{2}$ in $0.9 \% \mathrm{NaCl}$ and $\mathrm{rL}-1 \beta$ perfused pancreata was identical $(p>0.05)$ and all groups exhibited a significant increase in $\mathrm{PGE}_{2}$ release during the perfusion (Fig. $2 \mathrm{c}$ and $3 \mathrm{c}$ ), but no significant differences between the two groups were demonstrable at any given time during perfusion with 11 or $20 \mathrm{mmol} / \mathrm{l}$ of D-glucose.

\section{Islet morphology at the ultrastructural level}

Electron microscopic examination of islets in situ after rIL-1 $\beta$ perfusion (5 pancreata) revealed a significant amount of islet cell lysis as compared to $0.9 \% \mathrm{NaCl}$ perfused control pancreata $(n=4)$ (Table 3 ). Lysis was evident as disrupted plasma membranes and considerably lower staining of cytoplasm. For quantitation of lysis the number of cells in islet sections was determined and individual cells screened for intactness. Lysed cells still contained typical A- and B-cell granules (Fig. $4 \mathrm{a}$ and b). The lower or absent cytoplasm stain differs from the increased cytoplasm staining regularly seen in necrotic cells [14]. In four $0.9 \% \mathrm{NaCl}$ perfused glands 34 islets were identified and a total of 1553 cells counted. In five rIL-1 $\beta$ perfused glands the numbers were 31 islets and 1882 cells, respectively. As seen in Table 3, a small number of $\mathrm{A}$ as well as B cells were lysed in the $0.9 \% \mathrm{NaCl}$ perfused control pancreata. Perfusion with $\mathrm{rIL}-1 \beta$ resulted in increased lysis of all cell types, with a relatively higher increase of B-cell lysis than of A-cell lysis $(p<0.01)$. Still intact $B$ cells of rIL- $1 \beta$ perfused pancreata often exhibited unique cell protrusions, such a "bleb" was formed by a peripheral part of the B-cell cytoplasm, rarely contained insulin granules and exhibited a typical rearrangement of rough endoplasmatic reticulum (rER) membranes (Fig. $4 \mathrm{a}$ and $\mathrm{b}$ ). "Bleb" formation was never seen on A cells and only on $5 \mathrm{~B}$ cells surrounding a capillary in one islet of the $0.9 \% \mathrm{NaCl}$ perfused pancreata (in 6 of 1012 cells counted).

Fig. 4 a-c. Electron-microscopic islet morphology from two different recombinant interleukin-1 $\beta$ (rIL-1 $\beta$ ) perfused pancreata ( $a$ and b) and from a $0.9 \% \mathrm{NaCl}$ solution perfused pancreas (c). rIL-1 $\beta$ perfused islets revealed preferentially B-cell lysis (IB) and B-cell specific "bleb"-like cytoplasmatic protrusions $\left(^{*}\right)$ of still intact B cells $(a+b)$. "Blebs" rarely contained granules and showed typical rearrangement of rough endoplasmatic reticulum. The control pancreata exhibited a normal morphology. Magnification: $\times 5000$, the bar represents $2 \mu \mathrm{m}$

\section{Discussion}

Peripheral hyperinsulinaemia and hyperglucagonaemia are observed after i.v. administration of bacterial endotoxin to rats [15] and insulin secretion from perfused pancreata isolated from rats treated with endotoxins in vivo is enhanced [16]. However, co-perfusion with endotoxin does not affect insulin secretion from the isolated pancreas [17]. These observations imply the existence of a secondary agent, linking endotoxin to pancreatic hypersecretion. Among other effects, endotoxins induce production of IL-1 from macrophages [1], and treatment of rodents in vivo with culture supernatants from macrophages [18] or with rIL-1 $[19,20]$ induces hyperinsulinaemia and hyperglucagonaemia, as well as enhanced release of the two hormones from the glucose-stimulated isolated pancreas $[18,21]$. In the intact perfused rat pancreas we observed a concentration-dependent, stimulatory effect of rIL-1 $\beta$ on insulin release from the glucose-stimulated B cell, accompanied by stimulation of glucagon secretion, suggesting the existence of an endocrine effect of systemic IL- $1 \beta$ on A- and B-cell function in addition to the previously hypothesized local effect of IL-1 [3]. The observations of the present study support the hypothesis that hyperinsulinaemia and hyperglucagonaemia observed after endotoxin treatment and during the acute phase response [1] are mediated by an endocrine effect of IL-1 directly on the pancreatic A and B cell, indicating that IL-1 is the link between endotoxin and pancreatic hypersecretion in vivo. The concentration of systemic IL-1 during endotoxin infusions or severe infectious diseases have been reported to vary from $0.500 \mathrm{ng} / \mathrm{ml} \mathrm{[22]} \mathrm{to} 1.5 \mathrm{ng} / \mathrm{ml}$ [23]. The concentrations in our experiments are high, but because the cytokines adhere to proteins, the fraction of biologically active rIL-1 $\beta$ reaching the islet cells is unknown.

Our observations on the intact pancreas are identical to described effects of the cytokine on isolated islets during short-term exposure to IIL-1 $(<6 \mathrm{~h})$ [24]. Inhibition of insulin release as observed with isolated islets exposed to rIL-1 $\beta$ for more than $6 \mathrm{~h}$ [3] was not seen. Prolongation of rIL-1 $\beta$ exposure time from $60 \mathrm{~min}$, as described in our previous paper [7], to $92 \mathrm{~min}$, did not convert the potentiating effect on glucose-stimulated insulin release to inhibition. However, the dose-dependent stimulatory effect of rIL-1 $\beta$ exhibited a tendency towards a biphasic effect on second phase insulin release (Table 1). This observation could be explained by an inhibitory effect of rIL- $1 \beta$ at a high glucose concentration, starting to become apparent after perfusion for a longer period with higher concentrations of the cytokine ( $>14 \mathrm{ng} / \mathrm{ml}$ ).

This shift from stimulation to inhibition of insulin release by rIL-1 $\beta$ is supported by the morphological findings, which showed that $20 \%$ of the B cells were lysed and that the intact B cells were undergoing changes, as indicated by "bleb" formation. "Bleb" formation may be an early stage of cell death, as shown for TNF-induced cytolysis in fibroblast cells, in which the "bleb" formation is caused by destruction of the cytoskeleton, preceding lysis of the plasma membrane [25]. "Bleb" formation was not observed on isolated islets exposed to rIL-1 $\beta$ in vitro, but dilatation and derangement of the rER and B-cell lysis 
was found [26, 27]. However, B-cell lysis was more extensive in isolated islets [26]. We suggest that the effect of rIL$1 \beta$ on the perfused pancreas is heterogenous, dependent upon the flow through the perfused pancreas influencing the amount of rIL- $1 \beta$ reaching the islets. Furthermore, the effect is dependent upon the B-cell activity, in that the working cell is more sensitive than the resting cell [28], although very high glucose concentrations (i. e. higher than $22 \mathrm{mmol} / \mathrm{l}$ ) are protective [3, 27]. This is very pertinent as the $B$ cell population in the pancreas is heterogenous, consisting of a mixed population of resting and active cells [29]. Based on the morphological findings we believe that further prolongation of rIL-1 $\beta$ perfusion leads to inhibition of insulin release. However, duration of the experiments are limited by the viability of the in vitro perfused pancreas and pre-treatment in vivo for a longer period may be necessary for induction of inhibited insulin secretion [30].

Glucagon secretion was suppressed at all three D-glucose levels. This observation is not surprising, since the threshold for suppression of glucagon release is $<2.5$ $\mathrm{mmol} / \mathrm{l}$ glucose and because maximum suppression of glucagon release is obtained at $6-11 \mathrm{mmol} / 1$ of D-glucose [31]. rIL-1 $\beta$ induced a distinct stimulation of glucagon secretion at $5 \mathrm{mmol} / \mathrm{L} \mathrm{D}$-glucose and in spite of increasing insulin and D-glucose concentrations, rIL-1 $\beta$ induced a statistically significant increase in glucagon secretion at 11 and $20 \mathrm{mmol} / \mathrm{l}$ of $\mathrm{D}$-glucose as well $(p<0.0005)$. Furthermore, the rIL-1 $\beta$ stimulated glucagon secretion at $5 \mathrm{mmol} / \mathrm{l}$ of D-glucose could not be suppressed by an elevated glucose concentration from 72 to $84 \mathrm{~min}$, in spite of discontinued $\mathrm{rIL}-1 \beta$ perfusion, indicating that the sensitivity of A cells to glucose is changed by exposure to rIL$1 \beta$, making them unresponsive to an increase in glucose concentration. For comparison, rIL-1 $\beta$ potentiated first and second phase insulin release in response to a shift in D-glucose concentration from 5 to $11 \mathrm{mmol} / 1$ in spite of discontinued rIL-1 $\beta$ co-perfusion at $72 \mathrm{~min}$, suggesting that the $\mathrm{B}$ cells are hyperresponsive after exposure of rIL$1 \beta$ to $D$-glucose, as known for pancreata isolated from endotoxin-treated rats [15] and isolated islets after rIL-1 $\beta$ perifusion [32]. The stimulatory effect of rIL-1 $\beta$ on glucagon secretion at 11 and $20 \mathrm{mmol} / \mathrm{l} \mathrm{D}$-glucose may be blunted by a counter-acting A-cell inhibitory effect mediated by an increased insulin secretion, since it is known from experiments on the perfused pancreas that the order of islet cellular perfusion and functional interaction is from B to A to D cell [6]. However, these experiments do not rule out a paracrine regulation of islet hormones through the interstitial fluid spaces.

rIL- $1 \beta$ induces production of $\mathrm{PGE}_{2}$ from fibroblasts, muscle cells and endothelial cells [1] and rIL-1 $\beta$ stimulated cortisone release from the perfused adrenal is blocked by the cyclooxygenase inhibitor indomethacin [33]. Furthermore, since arachidonate metabolites - e.g. prostaglandins - may participate in glucose-stimulated insulin release $[34,35]$ and epinephrine/norepinephrinestimulated glucagon secretion [36], accordingly a prostaglandin-mediated stimulatory effect of rIL-1 $\beta$ on insulin and glucagon secretion was possible. However, we observed an increasing $\mathrm{PGE}_{2}$ release throughout the perfu- sion period in both $0.9 \% \mathrm{NaCl}$ and in rIL-1 $\beta$ perfused pancreata and only at $5 \mathrm{mmol} / \mathrm{l} \mathrm{D}$-glucose did co-perfusion with IIL-1 $\beta$ induce a higher release of the arachidonate metabolite. The major part of the released $\mathrm{PGE}_{2}$ probably originates from the exocrine tissue and, e.g., endothelial cells and platelets trapped in the tissue preparation.

In conclusion, the acute effect of rIL-1 $\beta$ on the intact perfused pancreas is characterized by stimulation of insulin and glucagon secretion, dependent upon $r \Pi L-1 \beta$ concentration and D-glucose level, with a tendency towards a bimodal effect, accompanied by induction of ultramorphological changes predominately in the B cells. We hypothesize that IL-1 $\beta$ in vivo may have an endocrine effect directly on the pancreas influencing A- and B-cell function and structure and should be investigated, not only as a physiological modulator of insulin and glucagon release, e.g. during the acute phase response, but also as a pathogenetic factor in Type 1 (insulin-dependent) diabetes mellitus in predisposed individuals.

Acknowledgements. The authors are grateful to Ms M. Munck, Ms E. Schjerning, Ms B.Sørensen and Ms A. Schlömer for technical assistance. Dr. Wogensen is the recipient of a fellowship award from the Weimann Foundation, Odense, Denmark, and the Juvenile Diabetes Foundation International, New York, USA. The study was also supported by grants from the Danish Diabetes Association, Nordisk Insulinlaboratorium, the Danish Medical Research Council (Barbara Sørensen) and by the Deutsche Forschungsgemeinschaft (grant Ko 806/2-2, V.Kolb-Bachofen).

\section{References}

1. Dinarello CA (1988) Biology of interleukin-1. FASEB J 2: 108115

2. Schultzberg M, Svenson SB, Unden A, Bartfai T (1987) Interleukin-1-like immunoreactivity in peripheral tissues. J Neurosci Res 18: 184-189

3. Mandrup-Poulsen T (1988) On the pathogenesis of insulin dependent diabetes mellitus. Dan Med Bull 35: 438-460

4. Spinas GA, Palmer JP, Mandrup-Poulsen T, Andersen H, Nielsen JH, Nerup J (1988) The bimodal effect of interleukin-1 on rat pancreatic beta-cells - stimulation followed by inhibition - depends upon dose, duration of exposure and ambient glucose concentration. Acta Endocrinol (Copenh) 118: 307-311

5. Nerup J, Mandrup-Poulsen T, Mølvig J, Helqvist S, Wogensen L, Egeberg J (1988) Mechanisms of pancreatic $\beta$-cell destruction in type 1 diabetes. Diabetes Care 11 [Suppl.1]: 16-23

6. Samols E, Stagner JI, Ewart RBL, Marks V (1988) The order of islet microvascular cellular perfusion is $B-A-D$ in the perfused rat pancreas. J Clin Invest $82: 350-353$

7. Wogensen LD, Mandrup-Poulsen T, Markholst H, Lernmark $\AA$, Holst JJ, Dinarello CA, Nerup J (1988) Interleukin-1 potentiates glucose stimulated insulin release in the isolated perfused pancreas. Acta Endocrinol (Copenh) 117:302-306

8. Svenningsen A, Dyrberg T, Markholst H, Binder C, Lernmark Å (1986) Insulin release and pancreatic insulin is reduced in young prediabetic BB rats. Acta Endocrinol 112:367-371

9. Dinarello CA, Cannon JG, Mier JW, Bernheim HA, LoPreste G, Lynn DL, Love RN, Webb AC, Auron PE, Reuben RC, Rich A, Wolff SM, Putney SD (1986) Multiple biological activities of human recombinant interleukin-1. J Clin Invest 77: 1734-1739

10. Dalbøge H, Bayne S, Christensen T, Heinæs KR (1989) Cloning and expression of an interleukin- $1 \beta$ precursor and its conversion to interleukin-1 $\beta$. FEBS 246: 89-93

11. Christensen P, Leyssac PP (1976) A specific radioimmunoassay for $\mathrm{PGE}_{2}$ using antibody with high specificity and a Sephadex 
LH-20 microcolumn for the separation of prostaglandins. Prostaglandins 11: 399-420

12. Christensen P, Green K, Leyssac PP (1983) The relationship between urinary prostaglandin excretion rates and urine flow in conscious rats. Evaluation of the radioimmunoassay by gas chromatography-mass spectrometry. Acta Physiol Scand 117: 41-47

13. Spurr A (1969) A low-viscosity epoxy resin embedding medium for electron microscopy. J Ultrastruct Res 26: 31-43

14. Farber S (1982) Biology of disease: membrane injury and calcium homeostasis in the pathogenesis of coagulation necrosis. Lab Invest 47: 114-123

15. Cornell RP (1983) Role of the liver in endotoxin-induced hyperinsulinemia and hyperglucagonemia in rats. Hepatology $3: 188$ 192

16. Yelich MR, Filkins JP (1980) Mechanism of hyperinsulinemia in endotoxicosis. Am J Physiol 239: E156-E161

17. Yelich MR, Filkins JP (1984) Role of calcium in the insulin hypersecretory state of the endotoxic rat pancreas. Circ Shock 14: 4962

18. Filkins JP, Yelich MR (1982) Mechanism of hyperinsulinemia after reticuloendothelial system phagocytosis. Am J Physiol 242: E115-E120

19. del Rey A, Besedovsky H (1987) Interleukin-1 affects glucose homeostasis. Am J Physiol 253: R794-R798

20. Pomposelli JJ, Flores EA, Bistrian BR (1988) Role of biochemical mediators in clinical nutrition and surgical metabolism. J Parent Ent Nutrition 12: 212-218

21. Yelich MR, Umporowicz DM, McCulla EA, Filkins JP (1987) Interleukin-1 (IL-1) in vivo potentiates immunoreactive insulin (IRI) secretion in the in vitro perfused rat pancreas. FED PROC 46: 4 (Abstract)

22. Reuter A, Bernier J, Gysen P, Gevaert Y, Gathy R, Lopez M, Dupont G, Damas P, Franchimont (1988) A RIA for tumor necrosis factor $(\mathrm{TNF} \alpha)$ and interleukin $1 \beta(\mathrm{IL}-1 \beta)$ and their direct determination in serum. In: Powanda MC (ed) Monokines and other non-lymphocytic cytokines. Alan R. Liss, New York, pp 377-381

23. Girardin E, Grau GE, Dayer JM, Roux-Lombard P, The J5 Study Group, Lambert PH (1988) Tumor necrosis factor and interleukin- 1 in the serum of children with severe infectious purpura. N Engl J Med 319:397-400

24. Spinas GA, Palmer JP, Egeberg J, Mandrup-Poulsen T, Andersen HU, Nielsen JH, Nerup J (1988) Differential effects of interleukin-1 on pancreatic alpha and beta cells. Diabetes 37 [Suppl.1]:202 (Abstract)

25. Scanlon M, Laster SM, Wood JG, Gooding LR (1989) Cytolysis by tumor necrosis factor is preceded by a rapid and specific dissolution of microfilaments. Proc Natl Acad Sci USA 86: 182-186

26. Mandrup-Poulsen T, Egeberg J, Nerup J, Bendtzen K, Nielsen JH, Dinarello CA (1987) Ultrastructural studies of time course and cellular specificity of interleukin-1 mediated islet cytotoxicity. Acta Path Microbiol Immunol Scand (C) 95: 55-63

27. Sandler S, Bendtzen K, Borg LAH, Eizirik DL, Strandell E, Welsh N (1989) Studies on the mechanisms causing inhibition of insulin secretion in rat pancreatic islets exposed to human interleukin- $1 \beta$ indicate a perturbation in the mitochondrial function. Endocrinology 124: 1492-1501

28. Palmer J, Helqvist S, Spinas GA, Mølvig J, Mandrup-Poulsen T, Andersen HU and Nerup J (1989) Interaction of beta-cell activity and interleukin- 1 concentration and exposure time in isolated rat islets of Langerhans. Diabetes 38: 1211-1216

29. Schuit FC, In'T Veld PA, Pipeleers DG (1988) Glucose stimulates proinsulin biosynthesis by a dose-dependent recruitment of pancreatic beta cells. Proc Natl Acad Sci USA 85: 3865-3869

30. Goodman M, Wang Y, Lumerman J, Sussman KE, Lafferty K, Drazin B (1988) Studies on the mechanism causing the impairment of glucose-stimulated insulin release in rat pancreatic islets exposed to human recombinant interleukin- $\beta$. Diabetes 37 [Suppl.1]: 21 (Abstract)

31. Gerich JE (1983) Glucose in the control of glucagon secretion. In: Lefebvre PJ (ed) Handbook of experimental pharmacology, Vol 66: Glucagon II. Springer, Berlin Heidelberg New York, pp 3-18

32. Zawalich WS, Dierolf B, Zawalich K (1989) Interleukin-1 induces time-dependent potentiation in isolated rat islets: possible involvement of phosphoinositide hydrolysis. Endocrinology 124 $720-726$

33. Roh MS, Drazenovich KA, Barbose JJ, Dinarello CA (1987) Direct stimulation of the adrenal cortex by interleukin-1. Surgery 102:140-146

34. Turk J, Colca JR, Kotagal N, McDaniel ML (1984) Identification and quantitation of lipoxygenase and cyclooxygenase products. I. Biochim Biophys Acta 794: 110-114

35. Turk J, Colca JR, Kotagal N, McDaniel ML (1984) Identification and quantitation of lipoxygenase and cyclooxygenase products. II. Biochim Biophys Acta 794: 125-136

36. Luyckx AS, Lefebre PJ (1983) Prostaglandins and glucagon secretion. In: Lefebvre PJ (ed) Handbook of exerimental pharmacology, Vol 66: Glucagon II. Springer, Berlin Heidelberg New York, pp 83-96

Received: 29 June 1989

and in revised form: 8 September 1989

Dr. J.Nerup

Steno Memorial Hospital

2 Niels Steensen Vej

DK-2820 Gentofte

Denmark 